\title{
Chapter 16 \\ Ted Nelson: A Critical (and Critically \\ Incomplete) Bibliography
}

\author{
Henry Lowood
}

\subsection{Introduction}

Devoting time to serious bibliographical matters as a tribute to Ted Nelson may seem like a quaintly out-of-tune and bookish, if not totally misguided project. It is easy to pigeon-hole Ted's work as belonging to a generation of adventurous and creative writers and editors active during the 1960s who began to find that traditional print media constrained the expression of their ideas. Marshall McLuhan and the Whole Earth Catalog come to mind. Indeed, Literary Machines opens with the declaration that it is "a hypertext, or nonsequential piece of writing." Each reader of this book has confronted the difficulties imposed by non-linear writing on the linear medium of print.

And yet, there is no way around the fact that most of Ted's work has been published on paper. This fact alone does not produce a particularly difficult problem for bibliography. The difficulty is rather that many of his important writings appeared in ephemeral or semi-published formats, ranging from conference proceedings and magazines of every ilk to self-published books that were produced anywhere and nowhere - at least from the perspective of libraries such as my own that tried desperately to acquire copies. As a result of the vagabond nature of the Nelson oeuvre, few libraries own more than a few of his published works, and several of his most important texts, such as the earliest editions of Computer Lib/Dream Machines and Literary Machines have achieved almost legendary status for being difficult to lay hands on. So where are we to turn for the texts?

Thus, this bibliography. At least it is a start. My goal has been to put together a complete picture of Ted Nelson's body of work as expressed in publication, including selections from ephemeral and non-print media. It has not been easy. As the

\footnotetext{
H. Lowood ( $\varangle)$

Stanford University Libraries, Stanford, CA, USA

e-mail: lowood@stanford.edu
} 
former bibliographer of the Society for the History of Technology, I adopted and long held to the habit of requiring visual inspection of texts that appeared in my bibliographies. Until this project, I had little reason to abandon this practice. Academic publication practices are easy to trace. It turns out that a number of Ted's publications have followed different paths to readers. Since they have often eluded library catalogs and on-line databases, I have had to trust sources such as c.v. entries, footnotes, and Web traces more than I would like. As a compromise with my earlier bibliographic rule, I have included most of what I have found, indicating works that I was unable to inspect with an asterisk preceding their entries in this bibliography. I ask that any readers who may have access to these texts to contact me. I will produce a revised version of this bibliography someday, if revisions are necessary as a result from any such contacts. Ted's work is worth it.

Open Access This chapter is distributed under the terms of the Creative Commons Attribution Noncommercial License, which permits any noncommercial use, distribution, and reproduction in any medium, provided the original author(s) and source are credited.

\section{Theodor H. Nelson Bibliography}

*Nelson TH, Caplan RL (1957) Anything \& everything: the 1957 Hamburg show at Swarthmore College. Audio recording - 33 1/3 rpm microgroove, Swarthmore

Nelson TH (1958) Schematics, systematics, normatics. http://tprints.ecs.soton.ac.uk/4/

Nelson TH (1959) The Epiphany of Slocum Furlow. https://www.youtube.com/ watch?v=rFgul6rwNbQ. Student film, Streamed video uploaded 2012.

*Nelson TH (1959) We need a sociology department. Swarthmore, PA. Collected essays written as an undergraduate at Swarthmore College

Nelson TH (1965) A file structure for the complex, the changing and the indeterminate. In: ACM '65: proceedings of the 20th national conference. Association for Computing Machinery, New York, pp 84-100. doi:10.1145/800197.806036. Paper 4.2 prepared for session 4, "Complex Information Processing," of the 1965 ACM Conference. Reprinted, with introduction by Noah Wardrip-Fruin. In: eds. Noah Wardrip-Fruin and Nick Montfort (eds) The new media reader. Cambridge: MIT Press, 2003, pp 133-45

Nelson TH (1965) Computer-indexed film handling. J SMPTE - Soc Motion Pict Telev Eng 74:818-819. (Preprint of conference presentation)

*Nelson TH (1965) Suggestion for an on-line Braille display. In: Proceedings of the society for information display. Society for Information Display. Paper presented to Sixth National Symposium on Information Display, Los Angeles, pp 31-39

*Nelson TH (1965) The hypertext. In: Proceedings of the World Documentation Federation

Nelson TH (1966-1967) Hypertext notes. http://web.archive.org/web/20031127035740/http:// www.xanadu.com/XUarchive/. Unpublished series of ten short essays or "notes"

Nelson TH (1967) Getting it out of our system. In: Schechter G (ed) Information retrieval: a critical review. Thompson Books, Washington, DC, pp 191-210

Nelson TH, Carmody S, Gross W, Rice D, van Dam A (1969) A hypertext editing system for the/360. In: Faiman M, Nievergelt J (eds) Pertinent concepts in computer graphics. Proceedings of the Second University of Illinois conference on computer graphics. University of Illinois Press, Urbana, pp 291-330 
Nelson TH (1970) Las Vegas confrontation sit-out: a CAI radical's view from solitary. ACM SIGCUE Outlook, October, 12-15. doi: 10.1145/965768.965770. "This is an account of a round-table discussion on computer contributions to curriculum which I chaired, or perhaps charred, at the Fall Joint Computer Conference, 1969. It was a mortifying experience: everyone walked out. Herewith my dutiful report"

Nelson TH (1970) Barnum-Tronics. Swarthmore Colleg Alumni Bull 12-15

Nelson TH (1970) The crafting of media. http://xanadu.com.au/ted/TN/PUBS/CraftMedia.html. "A short piece about the future design of electronic media, as I was thinking from 1960 to 1970 "

Nelson TH (1970) No more teachers dirty looks. Comput Decis September, 16-23 (Reprinted in Dream Machines (1974), 16-19, and, with introduction by Noah Wardrip-Fruin, In: The new media reader, Wardrip-Fruin N, Montfort N (eds) MIT Press, Cambridge, 2003, pp 308-316)

Nelson TH (1971) Computopia and cybercrud. In: Levien RE (ed) Computers in instruction: their future for higher education: proceedings of a conference held in October 1970. A Report Prepared for National Science Foundation and Carnegie Commission on Higher Education, pp 185-99. R-718-NSF/CCOM/RC. Santa Monica, CA; Washington, D.C.: The RAND Corporation; distributed by ERIC Clearinghouse. http://files.eric.ed.gov/fulltext/ED052635.pdf

*Nelson TH (1971) The route to Halftone image synthesis. Comput Decis May. Begins p. 12

Nelson TH (1973) A conceptual framework for man-machine everything. In: Proceedings of the June 4-8, 1973, National Computer Conference and Exposition, m21-26. AFIPS '73. ACM, New York. doi:10.1145/1499586.1499776

*Nelson TH (1973) As we will think. In: Online 72: conference proceedings ... International conference on online interactive computing, Brunel University, Uxbridge, 4-7 September 1972, pp 439-54. Uxbridge, England: Online Computer Systems, Ltd. Examines Vannevar's Bush 1945 essay. Reprinted In: James M. Nyce and Paul Kahn (eds) From memex to hypertext: Vannevar Bush and the mind's machine. Academic Press, Boston, 1991, pp 245-260

Nelson TH (1974) Computer Lib: you can and must understand computers now/dream machines: new freedoms through computer screens - a minority report. Chicago: Hugo's Book Service, for the author. Two books joined together in tête-bêche format. A reprint edition was created from negatives in 2013 by the author

Nelson TH, DeFanti TA, Sandin DJ (1975) Computer graphics as a way of life. Comput Gr 1(1):915. doi:10.1016/0097-8493(75)90026-6. Originally presented at the first SIGGRAPH Conference, 1974, with abstract published in SIGGRAPH ' 74 proceedings of the 1st annual conference on computer graphics and interactive techniques. ACM, New York, 1974, 4.

*Nelson TH (1975) Data realms and magic windows. In: ACPA-5: papers presented at the 5th conference - association of computer programmers and analysts

*Nelson TH (1976) [Television]. Chicago, January, 106. Untitled contribution to section called "Television," originally submitted under the title "Explorable Screens"

Nelson TH (1977) The home computer revolution. In: Nelson TH (ed) South Bend, Ind.; distributed by the Distributors

Nelson TH (1977) A dream for Irving Snerd. Creat Comput May-June, 79-81. Xanadu introduced in cartoon format. (Reprinted in The best of creative computing, vol. 3 (1980), 24-26)

Nelson TH (1977) PCC interviews Ted Nelson. People's Computer Company, February 5(4):41

Nelson TH (1977) Those unforgettable next two years. In: The first west coast computer faire: a conference \& exposition on personal \& home computers, 15-17 April 1977, San Francisco. conference proceedings. Computer Faire, Palo Alto, 20-25

Nelson TH (1978) Electronic publishing and electronic literature. In: DeLand EC (ed) Information technology in health science education. Plenum Medical, New York, pp 211-216

*Nelson TH (1979) Next year in Xanadu. Swarthmore, PA. Audio recording

Nelson TH (1980) ホームコンピュータ革命. Sotec, Inc., Tokyo. Translation of Home Computer Revolution by Nishi Jun'ichirō

Nelson TH (1980) Actors 2. The story continues (= "Symposium on Actor Languages", part 2). Creat Comput 6(11):73-94. (Edited collection of articles, with contributions by Nelson) 
Nelson TH (1980) Interactive systems and the design of virtuality. Creat Comput 6(11):56-62; (12):94-106

Nelson TH (1980) John Mauchly, 1907-1980. Creat Comput 6(3) March, 8. (A "personal reminiscence")

Nelson TH (1980) Replacing the printed word: a complete literary system. In: Information processing 80: proceedings of IFIP Congress 80: Tokyo, Japan October 6-9, 1980, Melbourne, Australia October 14-17, 1980, 1013-23. IFIP Congress Series 8. North-Holland Publishing, Amsterdam

Nelson TH (1980) Symposium on actor languages. Creat Comput 6(10):61-86 (edited collection of articles, with contributions by Nelson)

Nelson TH (1980) The Atari machine. Creat Comput 6(6):34-35

Nelson TH (1981) Literary machines: the report on, and of, project Xanadu concerning word processing, electronic publishing, hypertext, thinkertoys, tomorrows intellectual revolution, and certain other topics including knowledge, education and freedom. Theodor H. Nelson, Swarthmore (Subsequent re-publication dates appear to be: 1981, 1982, 1983, 1984, 1987, 1990, 1991, 1992 and 1993. The 1987 publication was a revision (version 87.1), as was the version published in 1992 and 1993 (version 93.1). Only the 1981, 1987, 1990, 1992 and 1993 publications could be verified against privately or institutionally held copies)

Nelson TH (1981) Mail Chauvinism: the magicians, the Snark and the Camel. Creat Comput 7(11):128-130, 134-138, 140-144, 150, 156. (Report on the Electronic mail and message conference)

Nelson TH (1982) A new home for the mind. Datamat, March, 169-180. Reprinted In: Mayer PA (ed) Computer media and communication: a reader. Oxford University Press, Oxford 2000

Nelson TH (1982) Smoothers of the lost arc. Creat Comput 8(3):86-110. Report describing the 1981 SIGGRAPH meeting

*Nelson TH (1982) Why computer ease is so difficult. In: Proceedings of control data software design conference, October 1982

Nelson TH (1983) The electronic office: how simple can you get? OAC' 83 Conference Digest. The Fourth Annual Office Automation Conference, 9-15

Nelson TH (1984) Computopia now! In: Digital deli: the comprehensive, user-lovable menu of computer lore, culture, lifestyles, and fancy. Workman Publishing, New York, pp 349-351

Nelson TH (1986) A technical overview of the Xanadu electronic storage and publishing system. VHS. [San Antonio, TX]: Project Xanadu. VHS

*Nelson TH (1986) A vision of the future. Publishers Weekly, November 23

Nelson TH (1986) The posterity machine. VHS. [San Antonio, TX]: Project Xanadu. VHS. Lecture at Vassar College, 1986

Nelson TH (1986c) The tyranny of the file. Datamat 32(24):83-86

Nelson TH (1987) All for one and one for all. In: Hypertext '87: proceedings of the ACM conference on hypertext. HYPERTEXT '87. ACM, New York. pp v-vii. doi:10.1145/317426.317427

Nelson TH (1987) Computer lib .../dream machines ... Tempus Books of Microsoft Press, Redmond, Revised and updated edition

Nelson TH (1987) Literary machines ... Edition 87.1. South Bend, Ind.: The Distributors. http:// archive.org/details/Literary.Machines.1987 ("Literary Machines, published by the author, 1981; various revisions from year to year; this is edition 87.1, being published by the author, 1987. Simultaneous mass-market edition being published by special arrangement by The Distributors, 702 South Michigan, South Bend IN 46618; simultaneous Macintosh hypertext edition in GUIDE being published by Owl International, Inc., 14218 NE 21st Street, Bellevue WA 98007")

*Nelson TH (1987) The checkmate proposal. ("Circulated as printout")

Nelson TH (1988a) Managing immense storage. Byte 13(1):225-238

*Nelson TH (1988) The call of the ocean: hypertext universal and open. Hyperage, May-June, 5-7

Nelson TH (1988b) Unifying tomorrow's hypermedia. In: Online information 88. 12th international online information meeting, vol 1. Learned Information, Oxford, pp 1-7

Nelson TH (1989) Hyperwelcome. Hypermedia 1(1):3-5. http://dl.acm.org/citation.cfm?id=66840 
*Nelson TH (1990) How hypertext (Un)does the Canon. Modern Language Association, Chicago (Usually cited by this title. Title given as "How Xanadu (Un) does the Canon" in the MLA Session Announcement published in Postmodern Culture 1, no. 1 (Sept. 1990))

Nelson TH (1990) Literary machines ... 89.1 edn. Mindful Press, Sausalito

Nelson TH (1990) On the Xanadu project. Byte, September, 298-299. Contribution to "Welcome to the Byte Summit: Sixty-three of the Most Creative and Influential People in the Industry Discuss Their Perspectives on the Microcomputer Industry of the Future"

Nelson TH (1990) The once and future literature. J Inf Sci 16(6):339-43. http://jis.sagepub.com/ content/16/6/339.short

Nelson TH (1990d) The right way to think about software design. In: The art of human-computer interface design. Addison-Wesley, Reading, pp 235-243

Nelson TH (1990) Virtual world without end. In: Proceedings of cyber arts international conference, September 1990. Keynote address published separately as Virtual World Without End. Mindful Press, Sausalito, 1990?

*Nelson TH, Jul E (1991) Theodor Nelson describes Xanadu: worldwide hypertext publishing. OCLC Newsletter, no. 194

Nelson TH (1992) Literary Machines ... 93.1 edn. Mindful Press, Sausalito

Nelson TH (1992) Literary Machines ... 93.1 edn. Mindful Press, Sausalito. (Electronic hypertext edition distributed by Eastgate Systems)

Nelson TH (1992) Literary machines 90.1: Il Projetto Xanadu. Padova: Muzzio. Translation of Literary Machines 90.1 into Italian

Nelson TH (1992d) Opening hypertext: a memoir. In: Tuman MC (ed) Literacy online, the promise (and Peril) of reading and writing with computers, Pittsburgh series in composition, literacy, and culture. University of Pittsburgh Press, Pittsburgh, pp 43-57

Nelson TH (1992) Silicon valley story, the preview 1.3. https://www.youtube.com/ watch?v=AXlyMrv8_dQ Excerpt (?) of "The Silicon Valley Show" uploaded in 2010 to YouTube

Nelson TH (1992) The silicon valley show. http://archive.org/details/Timothy_Leary_ Archives_189.dv. A video short called "The Silicon Valley Show" featuring Ted Nelson, Douglas Engelbart, Rick Mascitti, Stewart Brand, and Timothy Leary. Directed by Ted Nelson

Nelson TH (1992) Xanadu space, 1993. Autodesk, Sausalito. http://archive.org/ details/01Kahle000838. Wide Area Information Servers Project Documentation, scanned in 2013

Nelson TH (1993) Literary Machines ... 93.1 edn. Mindful Press, Sausalito, CA

Nelson TH (1993) Publishing contracts for a point-and-click Universe. Xanadu World Publishing Repository, Sausalito. http://archive.org/details/01Kahle000846. Wide Area Information Servers Project Documentation, scanned in 2013

Nelson TH (1993) The secret of human life. J Econ Soc Intell 3(2):84-94. http://tprints.ecs.soton. ac.uk $/ 5 /$. Adapted from manuscript draft of an as yet unpublished book, Biostrategy and Polymind. An article draft under the title, "The Secret of Human Life: A revisionist view of human psychology and evolution from the book in progress, Biostrategy and Polymind: A New Theory of Human Life," dated 8 Oct. 1987, is available here: http://tprints.ecs.soton.ac.uk/5/1/ seclife.txt

Nelson TH (1993) World enough: the manuscript edition. Mindful Press, Sausalito. http://archives. obs-us.com/obs/english/papers/ted/tedtoc1.htm. Autobiographical texts "under negotiation for serialization, and publishing this limited edition is part of that negotiation"

Nelson TH (1993) You will, Oscar, you will!: the implications of free quotability and transpublication. Xanadu World Publishing Repository, Sausalito. http://archive.org/details/01 Kahle000829. Wide Area Information Servers Project Documentation, scanned in 2013. Summary of address to the Annual Meeting of the Association of American University Presses, Salt Lake City, June 1993

Nelson TH (1994) リテラリーマシン: ハイパーテキスト原論. Tokyo: ASCII Corporation. Translation of Literary Machines 91.1 by Ikuo Takeuchi and Saito Yasushionore 
Nelson TH (1994b) A publishing and royalty model for networked documents. In: IMA intellectual property project proceedings, vol 1. Interactive Multimedia Association, Annapolis, pp 257-259

Nelson TH (1994) Xanadu: document interconnection enabling re-use with automatic author credit and royalty accounting. Inf Serv Use 14(4):255-265. http://iospress.metapress.com/index/ MH27753662736246.pdf

Nelson TH (1994) Xanadu publishing with royalty: 1994 One BBSCON. [S.1.]: PlaybackNow. com. Audio recording of lecture by Ted Nelson at the ONE BBSCON in August 1994 concerning his ideas for handling rights management in electronic publishing

Nelson TH (1995) The heart of connection: hypermedia unified by transclusion. Commun ACM 38(8):31-33. doi:10.1145/208344.208353

Nelson TH (1996) Issues in applicative hyperization of unwitting systems. In: ACM proceedings of the second international workshop on incorporating hypertext functionality into software systems, 1996. http://web.archive.org/web/20000613061623/http://www.cs.nott.ac.uk/ hla/ HTF/HTFII/Nelson.html. Paper delivered to HTF II - The Second International Workshop on Incorporating Hypertext Functionality Into Software Systems

Nelson TH (1997a) Crush and crash: logic of a terrible tomorrow. Commun ACM 40(2):90-91. doi:10.1145/253671.253729

Nelson TH (1997) Embedded markup considered harmful. In: XML: principles, tools and techniques, 2(4), Fall, 129-134. World Wide Web Journal, O'Reilly, Sebastopol. http://www.xml. com/lpt/a/294 or http://www.xml.com/pub/a/w3j/s3.nelson.html

Nelson TH (1997) Literature to last: design for a universal digital medium. In: Hagel U (ed) Labile Ordnungen: Netze Denken, Kunst Verkehren, Verbindlichkeiten. Interface 3. Hamburg: HansBredow-Institut für Rundfunk und Fernsehen, pp 98-102

Nelson TH (1997d) The future of information: ideas, connections and the gods of electronic literature. ASCII Corporation, Tokyo

Nelson TH (1997) Transcopyright: a simple legal arrangement for sharing, re-use and republication of copyrighted material on the net. In: Worldwide computing and its applications. International conference, WWCA'97. Proceedings. Lecture notes in computer science 1274. Springer, Berlin/New York, pp 7-14. http://link.springer.com/content/pdf/10.1007/3-54063343-X_34.pdf

Nelson TH (1997) Transcopyright: dealing with the dilemma of digital copyright. Educom Rev 32(1):32-35. http://eric.ed.gov/?id=EJ536232. "Cleanup" of Draft dated 14 Oct. 1998 available under the title, "Transcopyright: Pre-Permission for Virtual Republishing" at: http://www. xanadu.com.au/ted/transcopyright/transcopy.html

Nelson TH (1998) What's on my mind. In: Invited talk at the first wearable computer conference. Fairfax VA. http://xanadu.com.au/ted/zigzag/xybrap.html. Written version of paper delivered to first Wearable computer conference

Nelson TH (1998) Xanadu ZigZag hyperstructure kit: ZigZag commands for version 0.49. http:// www.xanadu.com/zigzag/zzDirex.html. "System designed by Ted Nelson, programmed by Andrew Pam. These instructions by TN"

Nelson TH (1999) The unfinished revolution and Xanadu. ACM Comput Surv 31(4es), December, article 37. doi:10.1145/345966.346039

Nelson TH (1999) Time to liberate the web. Inter@ctive Week, October 25

Nelson TH (1999) Way out of the box. October 8. http://ted.hyperland.com/TQdox/zifty. d9-TQframer.html

Nelson TH (1999) Xanalogical structure, needed now more than ever: parallel documents, deep links to content, deep versioning, and deep re-use. ACM Comput Surv 31(4es), December, article 33, 1-32. doi:10.1145/345966.346033

Nelson TH (2000) Many-to-many payments system for network content materials. http://www. google.com/patents/US6058381. US Patent 08/961,570, application dated 30 Oct 1997

Nelson TH (2001) Ted Nelson at ACM hypertext 2001 Streamed video. http://vimeo.com/15593138

Nelson TH (2001) Interactive connection, viewing and maneuvering system for complex data. http://www.google.com/patents/US6262736. US Patent application 09/530,857, application dated 15 Nov 1998 
Nelson TH (2001) The future of information (scanned). May 4. http://web.archive.org/ web/20010504071817/http://www.xanadu.com.au/ted/INFUTscans/INFUTscans.html

Nelson TH (2001) Xanadu technologies - an introduction, 4 October.” http://xanadu.com/tech/ (A Joint Disclosure by Udanax.com and Project Xanadu as of August 23, 1999 to accompany our presentation at the O'Reilly Open Source Conference.... [Updated to reflect what was actually said at the meeting, with clarifications of the illustrations that were shown. Further citations will be found in our ACM paper in preparation, "Xanalogical Structure: Needed Now More Than Ever" at http://www.xanadu.com.au/ted/XUsurvey/xuDation.html. See also our book Literary Machines])

Nelson TH (2001) The ZigZag® database and visualization system: the true generalization of structure, 11 January. http://xanadu.com/zigzag/

Nelson TH (2001) Zigzag (Tech Briefing). In: Proceedings of the 12th ACM conference on hypertext and hypermedia. ACM, New York, pp 261-262. http://dl.acm.org/citation.cfm?id=504281

Nelson TH (2002) Philosophy of hypertext. PhD dissertation, Keio University

Nelson TH (2003) I don't buy in. March. http://ted.hyperland.com/buyin.txt

Nelson TH (2003) Structure, tradition and possibility. In: Hypertext 03: the fourteenth ACM conference on hypertext and hypermedia, August 26-30, 2003, Nottingham, UK, 1. ACM, New York. doi:10.1145/900051.900053

Nelson TH (2004) A cosmology for a different computer universe: data model, mechanisms, virtual machine and visualization infrastructure. J Digit Inf 5(1). https://journals.tdl.org/jodi/ index.php/jodi/article/view/131/129

Nelson TH (2004) The world wide web at 10: the dream and the reality. Rose-Hulman Institute of Technology, Terre Haute, Audio recording of conference presentations

Nelson TH (2005) The politics of internet software: 'geeks bearing gifts.' Streamed video. http:// webcast.oii.ox.ac.uk/?view=Webcast\&ID=20051121_112. Oxford Internet Institute webcast

Nelson TH (2005) Transhyperability and Argumedia. New Rev Hypermed Multimed 11(1):27-32. doi:10.1080/13614560500202191. Invited commentary on D. Kolb, "Association and Argument: Hypertext In and Around the Writing Process," pp. 7-26 in this journal issue

Nelson TH (2005c) Translit (TM): the new open-source Xanadu. New Mag: Int Vis Verbal Commun 1:114-119

Nelson TH (2005) Transliterature ${ }^{\mathrm{tm}}$ : a humanist format for re-usable documents and media - deep, open, re-user-friendly, free-form, nonhierarchical, profusely connectable, 22 October. http:// transliterature.org/

Nelson TH (2006) It could all be so much better. New Sci 191(2569):54-55. http://www.sciencedirect.com/science/article/pii/S0262407906605046

Nelson TH (2006b) Lost in hyperspace. New Scientist 191(2561):26

Nelson TH, Smith RA (2007) Back to the future: hypertext the way it used to be. In: Proceedings of the eighteenth conference on hypertext and hypermedia. ACM, New York, pp 227-228. http:// dl.acm.org/citation.cfm?id=1286303. Text available at http://xanadu.com/XanaduSpace/btf.htm.

Nelson TH (2007) Toward a deep electronic literature: the generalization of documents and media. April 4. http://xanadu.com/XanaduSpace/xuGzn.htm

Nelson TH (2007) Transclusion: fixing electronic literature. https://www.youtube.com/ watch?v=Q9kAW8qeays. Streamed video of Google Tech Talk, 29 January

Nelson TH (2008) A very general lecture, Part 1. Streamed video. http://webcast.oii.ox.ac.uk/?vie w=Webcast\&ID=20080317_236. Oxford Internet Institute webcast

Nelson TH (2008) Geeks bearing gifts: how the computer world got this way. V. 1.1. Mindful Press, Sausalito; distributed by Lulu.com. http://www.lulu.com/shop/ted-nelson/geeks-bearing-gifts/paperback/product-4312837.html

Nelson TH (2008) System for exploring connections between data pages. http://www.google.com/ patents/US20090222717. U.S. Patent application 12/039,656, filed $28 \mathrm{Feb}$

Nelson TH (2010) Possiplex: movies, intellect, creative control, my computer life and the fight for civilization: an autobiography of Ted Nelson. Mindful Press, Hackettstown; distributed by Lulu.com. http://www.lulu.com/shop/ted-nelson/possiplex/ebook/product-17533977.html 
Nelson TH (2011) Dr Ted Nelson - interwingularity: when ideas collide. Resource. July 5. http:// videos.southampton.ac.uk/80/ or https://www.youtube.com/watch?v=EwPnOD8Qlpk. Streamed video of seminar held in 2007, University of Southampton, as part of 70th Birthday celebration

Nelson TH (2011) Ted Nelson on the future of text, Milde Norway, October 2011. Streamed video. http://vimeo.com/31039323

Nelson TH (2012) Computers for cynics, May. Available via the TheTedNelson YouTube channel, https://www.youtube.com/channel/UCr_DXJ7ZUAJO_d8CnHYTDMQ. Streamed video. Eight-part series on topics in the history of computing

Nelson TH (2013) Future of text 2013: Ted Nelson. Streamed video. https://www.youtube.com/ watch? $=$ SCoivDX3DFY\&feature=youtube_gdata_player. From the Future of Text Symposium at the London College of Communication, London, England, 2013

Nelson TH (2013) Ted Nelson at HomeBrew computer club reunion 11-11-13. Streamed video. https://www.youtube.com/watch?v=rbqPqp9y_1Q. Lecture at HomeBrew Computer Club reunion, 11 November, Computer History Museum

Nelson TH (2013) Ted Nelson's eulogy for Douglas Engelbart. Streamed video. https://www.youtube.com/watch?v=yMjPqr1s-cg. Given at the Computer History Museum in Mountain View, California, on 9 December

Nelson TH (2014) Intertwingled: Ted Nelson, 'what box?' Streamed video. http://ibc.chapman. edu/Mediasite/Play/83d7b9016e3a42ecaf112cc4620e719f1d. Concluding talk of the conference, "Intertwingled: The Work and Influence of Ted Nelson," Chapman College, Orange, 24 April

Nelson TH (2014) Life, love, college, etc, 2nd edn. Mindful Press. http://www.lulu.com/shop/ theodor-holm-nelson/life-love-college-etc/paperback/product-21479799.html. Collected essays written for the Swarthmore Phoenix as an undergraduate. Originally compiled in 1959 with the alternate title We Need a Sociology Department, and possibly reprinted at Reed College in 1992

Nelson TH (2014) The scene machine. Mindful Press, Sausalito; distributed by Lulu.com. http:// www.lulu.com/shop/theodor-holm-nelson/the-scene-machine/paperback/product-21454515. html

Nelson TH (2014) Ted Nelson home page. http://ted.hyperland.com/. Accessed 19 Dec. Website includes "Curriculum Vitae: Theodor Holm Nelson, Ph.D," http://hyperland.com/TNvita 